\title{
LIFE STRATEGIES OF SEMI-DESERT PLANTS: MECHANISMS OF DISPERSAL AND REPRODUCTION IN THE THERMOMEDITERRANEAN SHRUBLAND COMMUNITY ANABASIO-EUZOMODENDRETUM BOURGAEANI
}

\author{
by
}

\author{
ISABELL HENSEN ${ }^{\prime}$
}

\begin{abstract}
Resumen
HENSEN, I. (1999). Las estrategias de vida de las plantas semidesérticas: mecanismos de dispersión y reproducción en la comunidad de matorral termomediterráneo AnabasioEuzomodendretum bourgaeani. Anales Jard. Bot. Madrid 57(1): 63-79 (en inglés).

El presente trabajo describe los mecanismos de dispersión y reproducción en la comunidad de matorral termomediterráneo Anabasio hispanicae-Euzomodendretum bourgaeani. El análisis de las estrategias de vida se basa en inventarios fitosociológicos realizados en el desierto de Tabernas (provincia de Almería). La importancia biológica de las estrategias de vida es expresada por el cociente medio de la cantidad del grupo (GM). La estrategia de vida predominante es el subgrupo de los perennes con dispersión a corta distancia, con reproducción sexual. Las especies se reproducen principalmente por semillas y la reproducción clonal no parece tener importancia para la colonización del hábitat semidesértico. La comunidad está caracterizada por una baja capacidad de dispersión que se consigue por mecanismos que impiden la dispersión secundaria de las diásporas. Para asegurar que la germinación de las diásporas coincide con una economía hídrica favorable, un alto porcentaje de las especies que maduran y fructifican un poco antes o dentro del período seco almacena por lo menos una parte de sus diásporas en un banco aéreo. Además, la inmediata germinación de las diásporas es frecuentemente impedida por las altas temperaturas.
\end{abstract}

Palabras clave: Euzomodendron bourgaeanum, banco aéreo de diásporas, dispersión, estrategias de vida, producción de mucosidad, reproducción.

\begin{abstract}
HENSEN, I. (1999). Life strategies of semi-desert plants: mechanisms of dispersal and reproduction in the thermomediterranean shrubland community Anabasio-Euzomodendretum bourgaeani. Anales Jard. Bot. Madrid 57(1): 63-79.

The present study describes mechanisms of dispersal and reproduction in the thermomediterranean shrubland community Anabasio hispanicae-Euzomodendretum bourgaeani. The life strategy analysis based on sociological relevés was carried out in Tabernas Desert (Province Almería). The biological significance of the occurring life strategies is represented by the mean group quantity fraction (GM). The dominant life strategy subdivision of Anabasio-Euzomodendretum bourgaeani is that of Perennial stayers with short-range dispersal, with sexual reproduction. Reproduction takes place mainly by seeds; clonal reproduction does not appear to have any significance for the colonization of this semi-desert habitat. The community is characterized by a low dispersal capacity, achieved by several mechanisms for avoiding dispersal. A high percentage of the species that mature and fructify shortly before or during the hot and rainless summer, stores at least a subset of seeds in an aerial diaspore bank to assure that dispersal and germination coincide with an advantageous soil
\end{abstract}

' Institut für Systematische Botanik und Pflanzengeographie, Freie Universität Berlin. Altensteinstr. 6. D-14195 Berlin (Germany).E-mail: ihensen@zedat.fu-berlin.de. 
water supply. Additionally, immediate seed germination is frequently inhibited by high temperature.

Key words: Euzomodendron bourgaeanum, aerial diaspore bank, dispersal, life strategies, production of mucilage, reproduction.

\section{INTRODUCTION}

The shrubland community Anabasio hispanicae-Euzomodendretum bourgaeani Rivas Goday \& Esteve 1965 is among the floristically and ecologically most remarkable plant associations of the semi-arid habitats in Southeastern Spain. This association is rich in endemisms. It colonizes the inclined and highly eroded hillsides of the Tabernas Desert, a semi-desert landscape located in the north of Almería city (Almería Province, figs. 1-2).
The present study is mainly aimed to analyze the dominant life strategies within Anabasio-Euzomodendretum bourgaeani. The term life strategy is defined as a "system of co-evolved adaptive traits" developed by parallel differentiation and evolution of characteristics in different taxa (STEARNS, 1976; DURING, 1979). The concept was originally applied to the functional characterization of bryophyte communities (e.g. DuRING, 1979, 1981, 1992; FREY \& KÜRSCHNER, 1991a, b, 1995a, b; FREY \& al., 1995b; HALFMANN, 1991; GONZÁLEZ-MANCEBO \& al.,

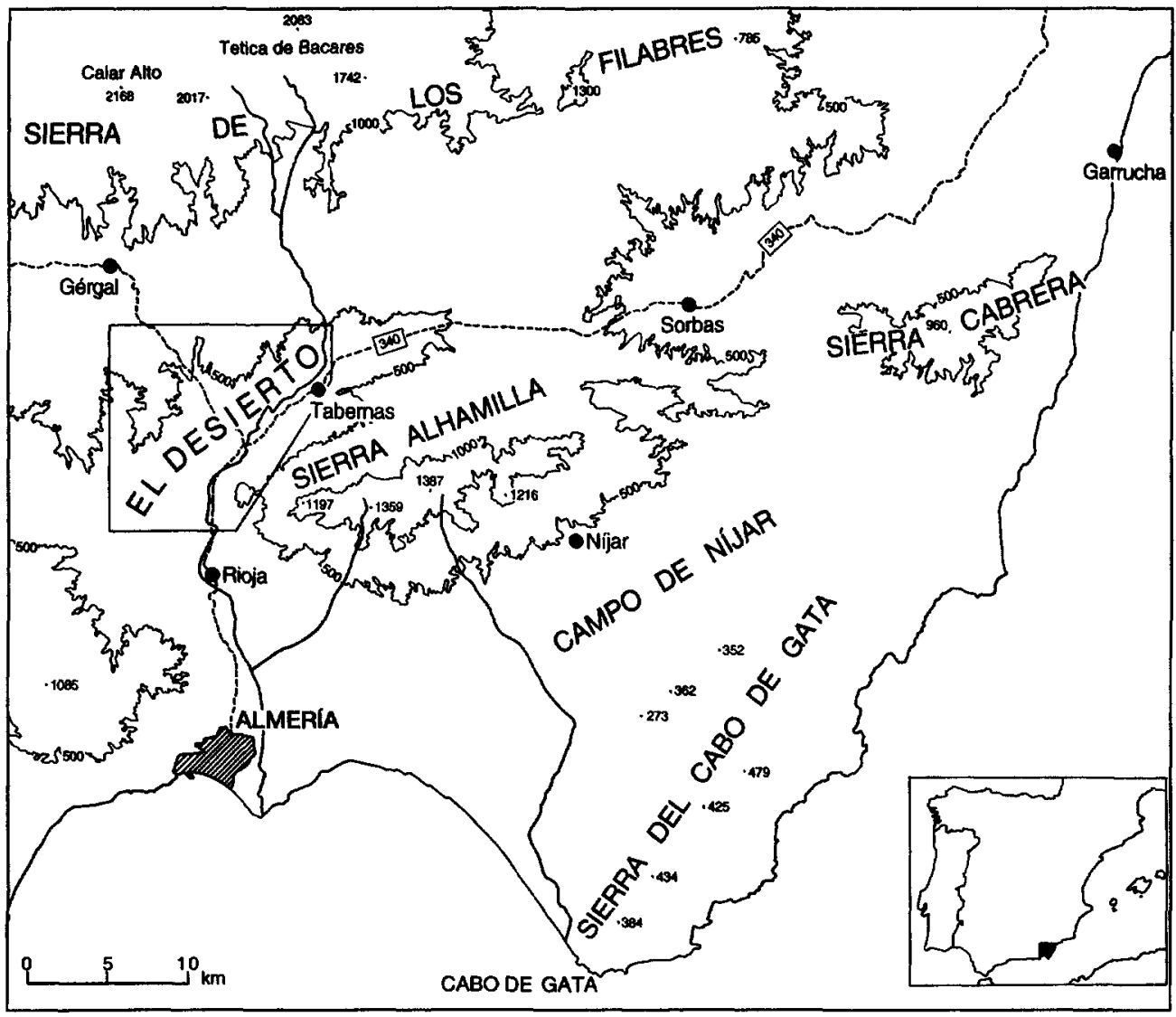

Fig. 1.-Location of the Tabernas Desert (Almeria, Southeastern Spain). 


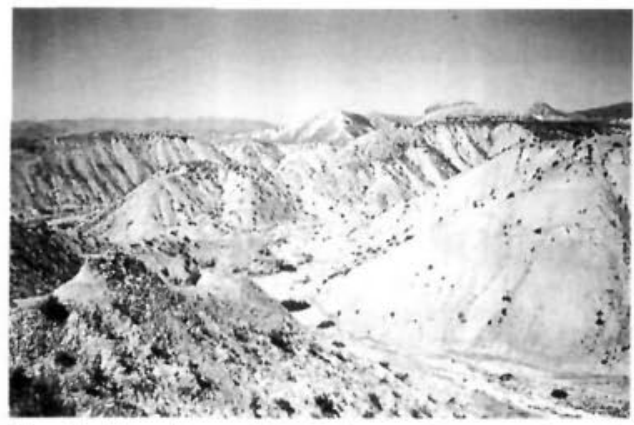

Fig. 2.-Overview of the Tabernas Desert (Almería, Southeastern Spain).

1992; KÜRSCHNER, 1994; ZIPPEL, 1998), and further developed by FREY \& HENSEN (1995a) for a synstrategical evaluation of communities dominated by phanerogames. FREY \& HENSEN's (1995a) classification focuses mainly on sexual and asexual mechanisms of dispersal and reproduction, and has been found to be applicable to several plant communities in Central Europe (e.g. FREY \& Hensen, 1995a, b; Frey \& Hauser, 1996; BÖTTNER \& al., 1997; HENSEN, 1997, 1998; Hensen \& Kentrup, 1998). Life strategy analyses provide information about groups of species characterized by the same strategies for colonization and recolonization, establishment, occupation, and maintenance of habitats, facilitating to assess the degree to which a plant community is endangered.

The present study is part of a research project analysing the predominant mechanisms of dispersal and reproduction in plant communities along an altitudinal gradient in the semi-arid habitats of Southeastern Spain, where the life strategies of four mediterranean communities have already been studied (SCHRAMM, 1998; GROENKE, 1999; Hensen, 1999c; Hensen \& Zuther, 1999).

\section{STUDY AREA}

The study area is the Tabernas Desert, situated $25 \mathrm{~km}$ north of the city of Almería, Andalucía, Southeastern Spain $\left(37^{\circ} 05^{\prime} \mathrm{N}\right.$, $2^{\circ} 25^{\prime} \mathrm{W}, 200-700 \mathrm{~m}$ above sea level; fig. 1). The climate in the area is semi-arid. The climatic diagram (fig. 3 ) gives a mean annual temperature of $17.3^{\circ} \mathrm{C}$ and a mean annual rainfall of $243 \mathrm{~mm}$. There is a pronounced and constant dry season from May to September, in contrast to a changeable annual rainfall from year to year (range of 41-365 mm between 1960 and 1990). Due to the marly substrates which establish the main geological basis of soil formation, nearly the whole Tabernas Desert has the characteristics of badland, with very eroded slopes and sparse vegetation (fig. 2).

\section{MATERIAL AND METHODS}

\section{Analysis of vegetation}

The quantitative analysis of the existing life strategies is based on the cover abundance index for all species composing the plant community. Eighteen relevés were carried out in May 1996 and June 1997, being classified in Anabasio-Euzomodendretum bourgaeani using BRAUN-BLANQUET's (1964) method (extended by BARKMAN \& al., 1964 and DIERSCHKE, 1994) and according to PEINADO

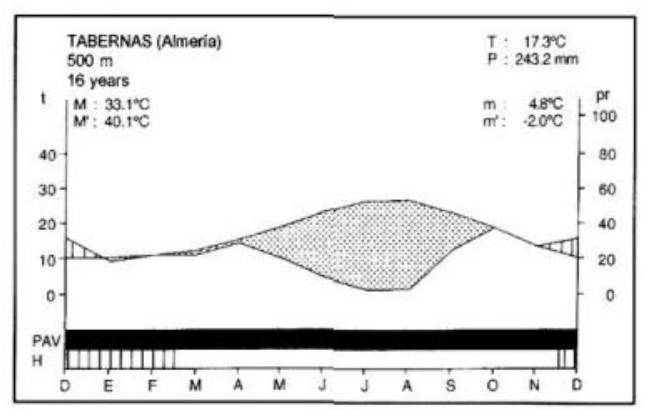

Fig. 3.-Climatic diagram of Tabernas (Almería, Southeastern Spain). $\mathrm{H}=$ probable frost period; $\mathrm{M}=$ mean maximum temperature of the warmest month; $\mathbf{M}^{\prime}=$ absolute maximum temperature of the warmest month; $\mathbf{m}=$ mean minimum temperature of the coldest month, $\mathrm{m}^{\prime}=$ absolute minimum temperature of the coldest month; $\mathrm{P}=$ mean annual rainfall in $\mathrm{mm}$; $\mathrm{pr}=$ precipitation $; \mathrm{PAV}=$ Period of vegetative activity; $\mathrm{T}=$ mean annual temperature $\mathrm{t}=$ temperature (according to PEINADO \& al., 1992, modified). 
\& al. (1992). Plant names were taken from Tutin \& al. (1968-1980, 1993), CASTROVIEJO \& al. (1990-1997), and NAVARRO (1995; Teucrium). Mosses and lichens were not studied. Measurements of soil profundity were carried out in several different areas to estimate soil water conditions.

\section{Classification of life strategies and evaluation of their biological significance}

Life strategy classification of the species comprising the plant community is based on FREY \& HENSEN (1995a, b), who elaborated a system of co-evolved adaptive traits to environmental conditions comprising life history, dispersal and reproductive behaviour (table 1). The biological significance can be calculated from the mean group quantity fraction (GM, comp. DIERSCHKE, 1994; FREY \& HENSEN, 1995a):

$$
\mathrm{GM}=\frac{\begin{array}{c}
\sum \text { of mean coverage percentage of all } \\
\text { group members within the association }
\end{array}}{\begin{array}{c}
\text { species occurring in the association } \\
(=\text { total coverage percentage })
\end{array}} \times 100
$$

Mean percentages of plant coverage are: $+(0.5 \%), 1(2.5 \%), 1 \mathrm{~m}(2.5 \%), 2 \mathrm{a}(10.0 \%)$, 2b (20.0\%), $3(37.5 \%), 4(62.5 \%), 5(87.5 \%)$; $r$ is not considered (DIERSCHKE, 1994; FREY \& Lösch, 1998). Estimation of dispersal behaviour (non-, long-range, short-range dispersal, shuttle) includes sexually and asexually produced diaspores. Clonal growth and clonal reproduction was determined in the study area. Clonal reproduction is defined as a fragmentation of a genet in morphologically similar ramets which are able to become independent. This mechanism results in a lateral spread of the individuum (HENSEN, 1997; FREY \& LöSCH, 1998).

\section{Dispersal behaviour of sexually produced diaspores}

Sexually produced dispersal units of all appearing species were collected in May 1996 and June, August and December 1997. They were classified according to JENNY (1995) into the following dispersal categories: acanthophorous: hooked; myxophorous: mucilaginous when wetted; pogonophorous: plumous by a pappus or hairy awn; pterophorous: winged; saccophorous: containing air; sarcophorous: fleshy; trypanophorous: turning around, creeping or drilling by hygroscopic movement; none: without characteristic furthering or hindering dispersal. It may be noted that the properties of diaspores do not necessarily correlate with the primary dispersal types: ballautochory: spread by mechanisms of turgescence or dessication; endozoochory: transported within animal intestines; epizoochory: transported by attachment to animals; meteoranemochory: able to fly; ombrohydrochory s.str.: diaspore released by rain, according to GUTTERMAN (1993); semachory: spread by movement (caused by wind or animals).

The presence of an aerial diaspore bank ("aestatiphory", ZOHARY, 1937) was ascertained in August 1997.

To determine the dispersal potential of meteoranemochorous seeds, flight experiments with morphologically distinct diaspores of Launaea lanifera, Lygeum spartum, and Stipa capensis were carried out using a nozzle-driven blower (method according to HENSEN \& MüLLER, 1997). At different wind speeds, 25 diaspores of each species were held in front of the opening, with the center of gravity lying below, and released. The trajectory was photographed against a black background, visible as a bright stripe in the transparency. Horizontal flight distances were calculated using the relation $x=h \tan \alpha$ ( $x=$ horizontal flight distance, $h=$ height of exposition, $a=$ angle between the trajectory and the vertical line).

\section{Germination experiments}

Germination experiments with freshly collected and 6 month dry-stored diaspores of Diplotaxis harra subsp. lagascana, Euzomodendron bourgaeanum, Lygeum spartum, Moricandia foetida, Phagnalon rupestre, Serratula flavescens, Stipa capensis, S. parviflora, and S. tenacissima were carried out in order to obtain information about dormancy 


\section{TABLE 1}

LIFE STRATEGY SYSTEM

(according to FREY \& HENSEN, 1995a, b)

1. Annual shuttle species

Short life span (annual), short-range dispersal of sexual diaspores (shuttle), sexual reproduction effort high, no asexual reproduction.

2. Fugitives

Short life span (annual, biennial), long-range dispersal of sexual diaspores, sexual reproduction effort high, asexual reproduction infrequent.

3. Cryptophytes (= Geo-, Helo-, Hydrophytes)

Perennials, long- and short-range dispersal of sexual diaspores, sexual and asexual reproduction frequent.

4. Short-lived shuttle species

Biennials or pauciennials, short-range dispersal of sexual diaspores (shuttle), sexual reproduction frequent, asexual reproduction infrequent.

5. Colonists

Mainly pauciennials, long-range dispersal of sexual diaspores, sexual reproduction effort high, asexual reproduction frequent.

6. Perennial colonists

Perennials, high mortality rates, long-range dispersal of sexual diaspores, sexual reproduction effort high, asexual reproduction infrequent.

7. Perennial shuttle species

Perennials, short-range dispersal of sexual diaspores (shuttle), sexual reproduction effort high, asexual reproduction frequent.

8. Perennial stayers

Perennials, non or long- and short-range dispersal of sexual diaspores, sexual and asexual reproduction frequent.

9. Perennial stayers with diaspore years

Perennial trees setting fruits only in certain periods ("mast years"), thus building up a deposit of juvenile plants. Long- and short-range dispersal of sexual diaspores, sexual and asexual reproduction frequent.

\section{Subdivision}

according to dispersal potential of sexual and/or asexual produced diaspores

with long-range dispersal (Telechory)

with short-range dispersal (Engychory)

with long- and short-range dispersal (Telechory and Engychory)

according to reproduction type

with sexual reproduction

with asexual reproduction s.str.

with clonal reproduction

with passive reproduction 
types. Germination was tested in climate chambers with a warm white light source (12 h of light / $12 \mathrm{~h}$ of darkness) providing $20 \mu \mathrm{mol} \mathrm{m} \mathrm{s}^{-1}$ at seed level at four fluctuating temperatures: $8 / 2{ }^{\circ} \mathrm{C} ; 16 / 10^{\circ} \mathrm{C} ; 24 / 18^{\circ} \mathrm{C}$; $32 / 24^{\circ} \mathrm{C}$. Each experiment consisted of three replicate Petri dishes with at least 50 viable seeds. A seed was considered to have germinated when its radicle had become elongated.

\section{RESULTS}

\section{Syntaxonomy and habitat conditions of Anabasio-Euzomodendretum bourgaeani}

The endemic association Anabasio-Euzomodendretum bourgaeani is found on the steep and highly eroded slopes between Rioja and Tabernas (figs. 1-2). This permanent-type community grows on poorly developed soils without upper horizon. The marly subsoils of an almost white to light grey color are frequently covered by a saline crust over the soil surface. The soil profundity of the predominant entisols is low. Because they are heavily compressed and have very poor infiltration characteristics, the mean field layer coverage of vegetation is only about $10 \%$ (table 2).

Anabasio-Euzomodendretum bourgaeani is one of the plant communities on the Iberian Peninsula richest in endemic species (table 2). It is sociologically included within Rosmarinetea officinalis $\mathrm{Br}$-Bl. 1947 em. RivasMartínez et al. 1991 (Anthyllidetalia terniflorae Rivas Goday et al. in Rivas Goday \& Borja 1961). Characteristic taxa of association are two locally endemic Brassicaceae: Euzomodendron bourgaeanum and Moricandia foetida (PeInado \& al., 1992). Among the character species of Anthyllidetalia terniflorae, Launaea lanifera is highly constant (table 2).

\section{Predominating mechanisms of sexual and asexual reproduction}

The character complex determining the life strategies of Anabasio-Euzomodendretum bourgaeani is compiled in table 3 . It indicates that most species of Anabasio-Euzomodendretum bourgaeani mature and fructify shortly before or during the drought period. Almost $40 \%$ of these keep all or part of their seeds within an aerial diaspore bank, so that at least a few diaspores remain attached to the mother plant until the next rainy season.

A survey of the predominant mechanisms of dispersal and reproduction (table 4) shows that within Anabasio-Euzomodendretum bourgaeani, sexual reproduction is far more significant than asexual reproduction. Only $6.9 \% \mathrm{GM}$ of the species are capable of clonal reproduction. There is a clear dominance of sexually produced diaspores provided with flying structures, such as wing-like formations or plumous hairs, and diaspores with mucilage production. Meteoranemochory is the predominant dispersal type (46.4\% GM; table 4). However, meteoranemochory does not necessarily result in long-range dispersal; only diaspores with well-established flight structures could be dispersed by wind over longer distances (figs. 4a-c). Other significant dispersal types are ombrohydrochory s.str. (31.5\% GM) and ballautochory (30.4\% GM; table 4).

\section{Life strategies}

The following life strategy subdivisions are of biological significance within Anabasio-Euzomodendretum bourgaeani (fig. 5): perennial stayers with short-range dispersal and sexual reproduction ( $\mathrm{PE}_{\mathrm{s}} ; \mathrm{GM}$ $43.6 \%$ ), perennial stayers with long-range dispersal and sexual reproduction $\left(\mathrm{PT}_{\mathrm{s}} ; \mathrm{GM}\right.$ $26.3 \%$ ), fugitives with long- and short-range dispersal and sexual reproduction $\left(\mathrm{FuTE}_{\mathrm{s}}\right.$; GM $8.8 \%$ ), and annual shuttle species (AnS; GM $6.3 \%$ ). It is remarkable that almost all perennial stayers belong to the chamaephytic life form (table 3).

Perennial stayers with short-range dispersal and sexual reproduction $\left(P E_{s}\right)$

Perennial stayers with short-range dispersal and sexual reproduction is the 
TABLE 2

ANABASIO HISPANICAE-EUZOMODENDRETUM BOURGAEANI OF THE TABERNAS DESERT, SOUTHEASTERN SPAIN

(*Iberian endemisms)

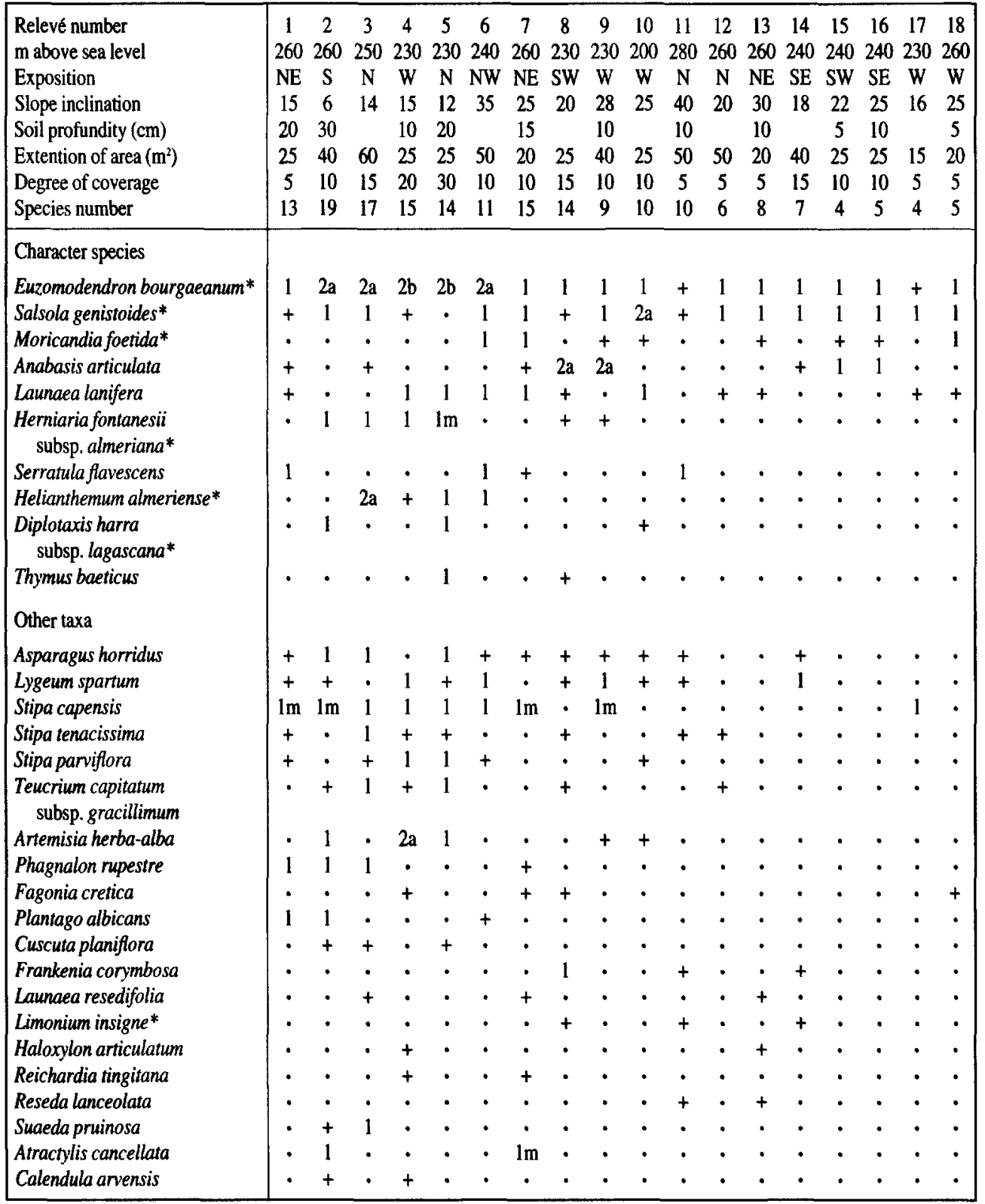

Additional taxa: in 1: Lobularia maritima 1; in 2: Asteriscus aquaticus 1, Linum strictum 1, Salsola oppositifolia +, Thesium humile +; in 3: Carlina racemosa + , Limonium tabernense* 1 , Thapsia villosa $+;$ in 7: Bromus rubens $1 \mathrm{~m}$, Helianthemum salicifolium +; in 8: Genista umbellata + ; in 10: Launaea arborescens 1; in 12: Reseda phyteuma +; in 16: Lycium intricatum +.

Relevé locations: Tabernas Desert. 


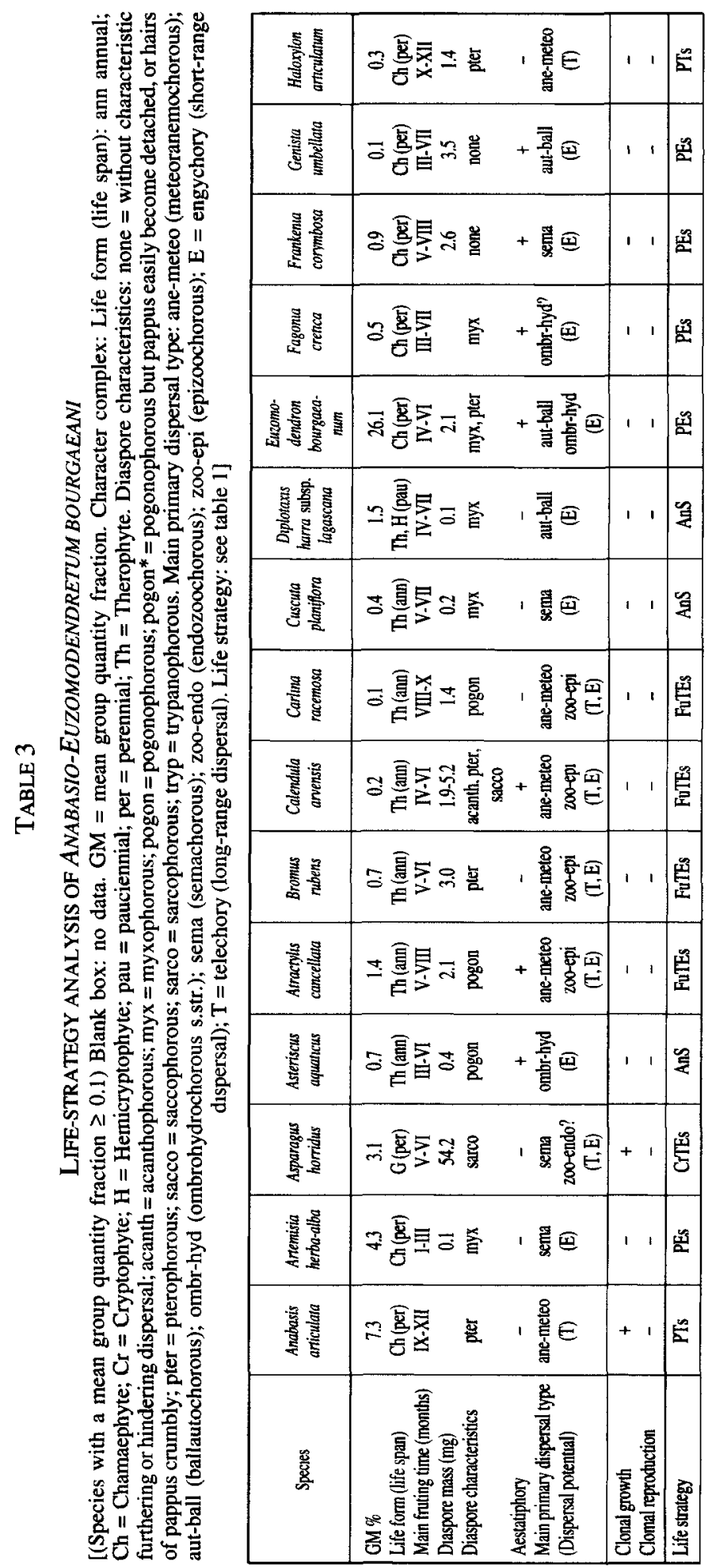




\begin{tabular}{|c|c|c|c|c|c|c|c|}
\hline 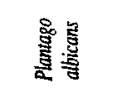 & 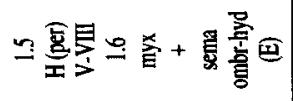 & +1 & t & & & & \\
\hline 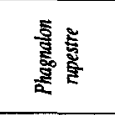 & 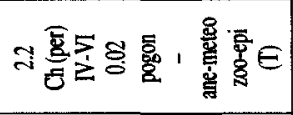 & 1 & $\stackrel{\circ}{\circ}$ & 蛋 & 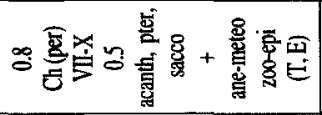 & & 鯜 \\
\hline 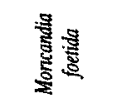 & 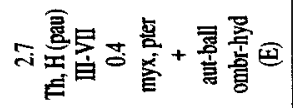 & 11 & 量 & 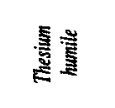 & 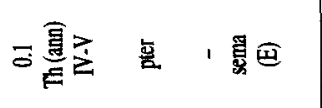 & 1 & 管 \\
\hline 㶻 & 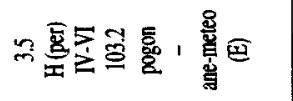 & ++ & 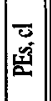 & 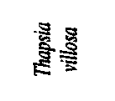 & 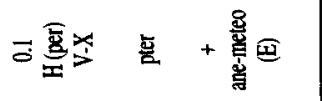 & 1 & 里 \\
\hline 意意 & 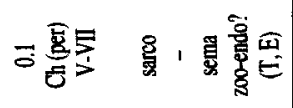 & 11 & 鱼 & 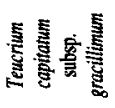 & 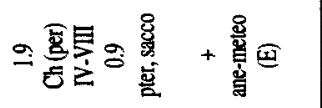 & 11 & 혈 \\
\hline 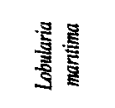 & 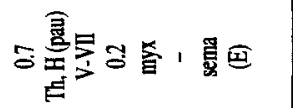 & 1 & a & 苞量 & 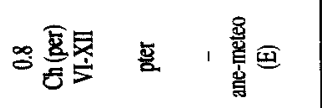 & +1 & 분 \\
\hline 焉 & $8 \frac{5}{5}$ & 11 & 常 & 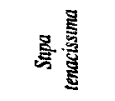 & 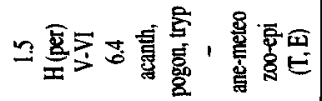 & ++ & $\begin{array}{l}\bar{s} \\
\text { 迎 }\end{array}$ \\
\hline 讋 & 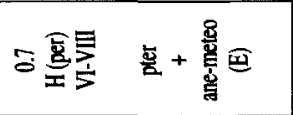 & +1 & 異 & 善哀 & 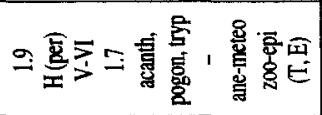 & +1 & 焉 \\
\hline & 接害离 & + & $\ddot{m}$ & 量善 & 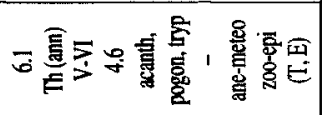 & , & 魚 \\
\hline & 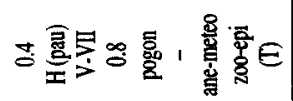 & 1, & 5 & 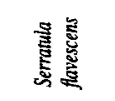 & 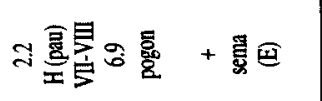 & ' & ă \\
\hline & 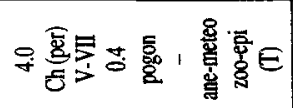 & 1 & $\tilde{\xi}$ & 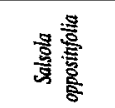 & 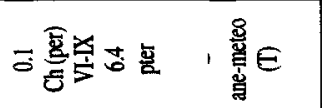 & +1 & 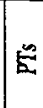 \\
\hline & 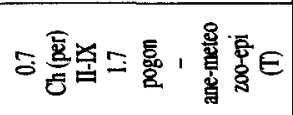 & , 1 & $\ddot{\Sigma}$ & 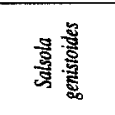 & 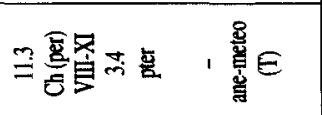 & 11 & 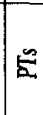 \\
\hline 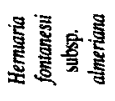 & 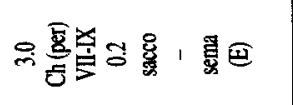 & +1 & $\ddot{q}$ & 悹意 & 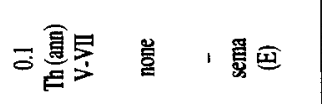 & 1 & 管 \\
\hline 震量 & 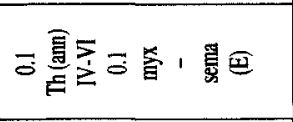 & 11 & 勾 & 㝬 & 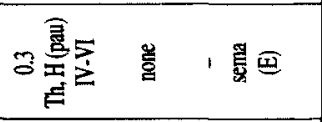 & 1 & $a$ \\
\hline 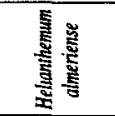 & 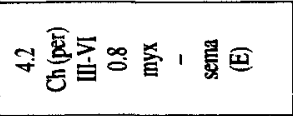 & 1 & $\frac{4}{2}$ & 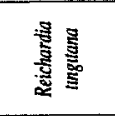 & 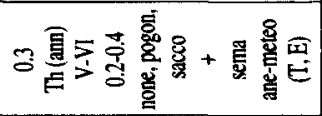 & & 米 \\
\hline & 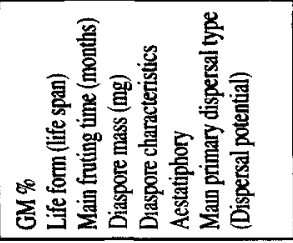 & 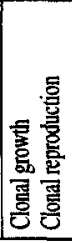 & 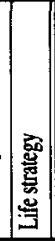 & & 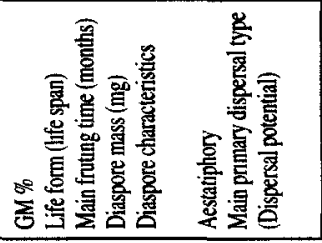 & 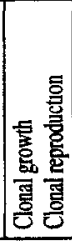 & \\
\hline
\end{tabular}


dominant life strategy subdivision of Anabasio-Euzomodendretum bourgaeani. The most significant representatives are chamaephytes: Euzomodendron bourgaeanum, Artemisia herba-alba, Helianthemum almeriense, and Herniaria fontanesii subsp. almeriense.

The locally endemic character species Euzomodendron bourgaeanum (Brassicaceae), with a GM of $26.1 \%$, clearly dominates the community. Its population is composed of different age groups. The shrub grows up to a height of approximately $50 \mathrm{~cm}$ and is characterized by dehiscent carneous pinnate leaflets.

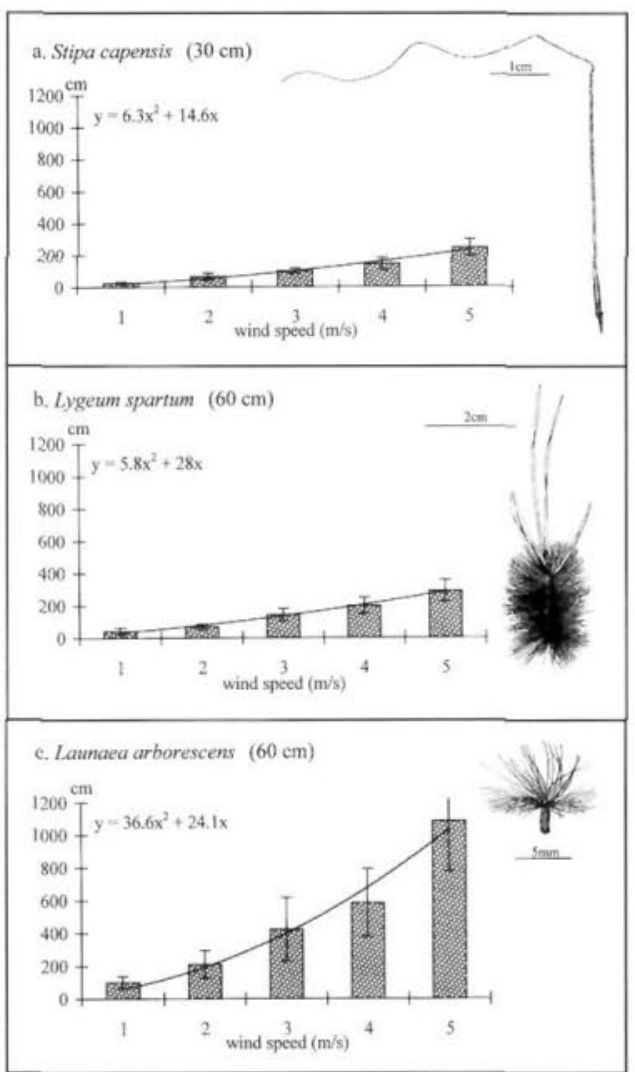

Figs. 4a-c.-Horizontal flight distance $(\mathrm{cm})$ in dependence of wind velocity (mean value and span for $n=25$ ) of diaspores of Stipa capensis: a, Lygeum spartum; b, and Launaea arborescens; c (data of Lygeum spartum provided by GROENKE, 1999). In brackets: exposition height of diaspores. The quadratic equations describe the dispersal behaviour.

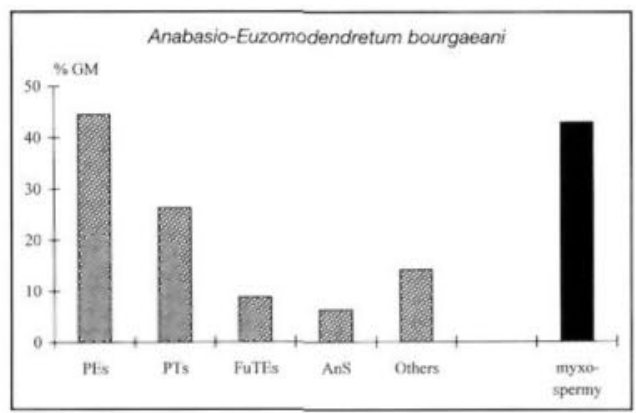

Fig. 5.-Life strategy spectra of Anabasio-Euzomodendretum bourgaeani, and biological significance of myxospermy as the most important mechanism preventing dispersal. Analysis based on the mean group quantity fraction (GM). Other life strategy subdivisions: $\mathrm{PE}_{\mathrm{s}, \mathrm{cl}}$; GM $3.5 \%$; PTEs,cl; GM $3.4 \%$; PaS; GM $3.2 \%$; CrTEs; GM $3.1 \%$; PTEs; GM $0.9 \%$. For abbreviations of life strategies see table 1 .

Its siliquas contain 16 winged seeds on average, which develop mucilage after being wetted (fig. 6). Diaspores are dispersed predominantly between April and June, but a

\section{TABLE 4}

MEAN GROUP QUANTITY FRACTION (GM) OF CLONAL GROWTH, CLONAL REPRODUCTION, AND CHARACTERISTICS OF SEXUALLY PRODUCED DIASPORES AND DISPERSAL WITHIN ANABASIOEUZOMODENDRETUM BOURGAEANI

\begin{tabular}{|l|c|}
\hline & GM \% \\
\hline Clonal growth / clonal reproduction & $23.8 / 6.9$ \\
\hline Diaspore characteristics & \\
pterophorous & 53.5 \\
myxophorous & 42.7 \\
pogonophorous / pogonophorous* & $22.5 / 2.5$ \\
acanthophorous & 10.5 \\
trypanophorous & 9.5 \\
none & 3.8 \\
sarcophorous & 3.2 \\
saccophorous & 3.2 \\
\hline Main primary dispersal type & \\
meteoranemochory & 46.4 \\
ombrohydrochory s.str. & 31.5 \\
ballautochory & 30.4 \\
epizoochory & 20.0 \\
semachory & 18.8 \\
endozoochory & 3.2 \\
\hline
\end{tabular}


small fraction remains on the mother plant during the drought period (partial aestatiphory). The ballautochorous seeds are spread by an explosion mechanism under the influence of a sudden movement. Such movement can be caused by gusty wind, rain, or animals. Field observations show that the seeds disperse up to $1.5 \mathrm{~m}$ through this primarily dispersal mechanism. Under humid weather conditions, secondary transport of seeds is prevented by the production of sticky mucilage. The capacity of the seeds to adhere to soil crust is very strong. The seeds remain attached to the soil even under a wind of $18 \mathrm{~m} / \mathrm{s}$ (unpublished data). This mechanism may also prevent major predation by harvester ants. Seeds of Euzomodendron bourgaeanum germinate in a wide range of temperatures $\left(8-32{ }^{\circ} \mathrm{C}\right)$. There is no innate dormancy, but germination is clearly reduced at temperatures over $24^{\circ} \mathrm{C}$ (fig. 7a).

The locally endemic Herniaria fontanesii subsp. almeriana (Caryophyllaceae) develops its saccophorous diaspores immediately above ground level, where any further transport is prevented by the plant's own densely arranged small leaves. The chamaephytes Artemisia herba-alba and $\mathrm{He}$ lianthemum almeriense are characterized by the development of myxophorous diaspores. These are spread out semachorously, and adhere strongly to the soil surface under the influence of rain. The diaspores of Artemisia herba-alba mature during the rainy season, when the time of seed maturation is close to the time of seed germination. The seeds of Helianthemum almeriense drop out of their capsules shortly before the drought period.

\section{Perennial stayers with long-range} dispersal and sexual reproduction $\left(P T_{s}\right)$

Salsola genistoides, Anabasis articulata, Launaea lanifera, and Phagnalon rupestre are the most significant representatives of this group. Seeds of Salsola genistoides and Anabasis articulata (Chenopodiaceae) mature and germinate during the rainy period. Their small nutfruits remain enclosed by the tepals which enhance their flight efficiency (see HENSEN, 1999a for Salsola genistoides). Long-range dispersal is equally promoted by pappus in Launaea lanifera (see fig. $4 \mathrm{c}$ for the similar stuctured achenes to Launaea arborescens) and Phagnalon rupestre (Asteraceae). The latter is characterized by xerochastic capitula which enclose their seeds when wetted, and expose them when atmospheric humidity is very low. The aerodynamic diaspores of Phagnalon rupestre are very small however $(0.02 \mathrm{mg}$; table 3). After being dispersed at the beginning of summer, they rapidly become covered by dust and other soil particles. Germination experiments reveal that they remain dormant for at least six months.

\section{Fugitives with long- and short-range dispersal and sexual reproduction $\left(F u T E_{s}\right)$}

This subdivision is represented by Stipa capensis, one of the most common annual grasses of southeastern Spain. This therophyte completes its life cycle by producing and dispersing mature caryopses at the beginning of the drought period. The spikelets are characterized by a long lemma-awn which serve as a flight mechanism. However, at a wind speed of $5 \mathrm{~m} / \mathrm{s}$, diaspores of Stipa capensis reach short flight distances not longer than approximately $2 \mathrm{~m}$ (fig. 4a). Additionally, during the process of fruit ripening, their awns often keep hooked together in a way that several caryopses are blown away as a single, much heavier dispersal unit (synaptospermy). Long-range

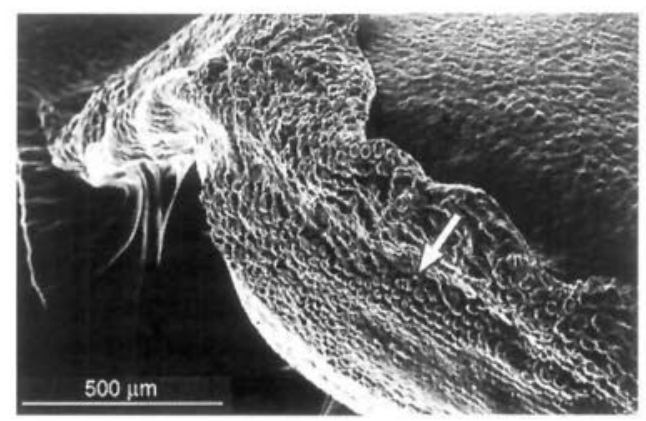

Fig. 6.-Euzomodendron bourgaeanum: seed in moist condition (mucilaginous cells marked by an arrow). 
dispersal, on the other hand, is easily promoted by attachment to animals. The importance of such process of epizoochory should be investigated in this habitat.

The diaspores of Stipa capensis are trypanophorous: the lower part of the awn twists when dry and straightens when wet. They are able to penetrate the soil where at least a part of them remain dormant until the next rainy season. Then, after several months of after-ripening, all caryopses are able to germinate within a few hours and under a wide range of temperatures (fig. $7 b$ ).

\section{Annual shuttle species (AnS)}

Annual shuttle species are represented by eight therophytes. It is remarkable that five of them, including Moricandia foetida and Diplotaxis harra subsp. lagascana (Brassicaceae) develop myxophorous seeds. Ballautochorous seeds of this two species spread out from the narrow siliquas shortly before the drought period. In case of high site humidity, they stick firmly to the ground and become buried. Although similar in their ecology, both species display a distinct germination behaviour. The immediate germination of the diaspores of Moricandia foetida is prevented by an innate dormancy whereas germination of freshly collected Diplotaxis harra subsp. lagascana diaspores takes place only when soil temperatures are low (results not shown).

\section{Other life strategy types}

Lygeum spartum (Poaceae), a perennial stayer with short-range dispersal and sexual and clonal reproduction, is among the few clonally reproducing species existing within Anabasio-Euzomodendretum bourgaeani. The fragments of a clone consist of a large number of ramets which are lined up like pearls on a string. The lemmas of the caryopses are covered with long silky hairs and keep together in pairs, thereby enclosing 2 grains that remain connected until germination. The flight capacity of these synaptospermous diaspores is low (fig. 4b). Germination of non-dormant seeds is carried out under a wide range of temperature conditions (fig. 7c). It seems likely that timing of germination is regulated by the duration and degree of wetting.

Stipa parviflora and S. tenacissima (Poaceae) are perennial stayers with longand short-range dispersal and sexual and clonal reproduction. They develop an extensively branched rhizome that fragments by withering. In terms of their dispersal behaviour, fruits of both species are similar to those of Stipa capensis (fig. 4a). No innate dormancy is found, but germination is inhibited at higher temperatures in Stipa tenacissima (fig. 7d).

The biennial Serratula flavescens (Asteraceae), a short-lived shuttle species, develops xerochastic capitula which enclose its seeds when wetted, and open them when atmospheric humidity is very low. However, during the summer, diaspores of Serratula flavescens are held deep in the capitula, where they are additionally protected by dense and abundant receptacular bristles. Seeds are characterized by inhibited germination under high temperatures (fig. 7e).

\section{DISCUSSION}

In the thermomediterranean landscape of the Tabernas Desert, the locally endemic Anabasio hispanicae-Euzomodendretum bourgaeani is the dominant association on the highly eroded hillsides of the region. The high number of endemic species to Southeastern Spain indicates that these badland areas have been formed naturally. The denuded slopes may have already been in existence during the more humid glacial periods, because the lightrequiring species are not able to compete within a dense vegetation structure (FREITAG, 1971).

In this semi-desert environment, a system of specific co-evolved adaptive traits to the climatically and edaphically extreme habitat conditions has been developed. A quantitative evaluation of the existing colonization and reproduction mechanisms, as assessed by converting species amplitude and constancy 

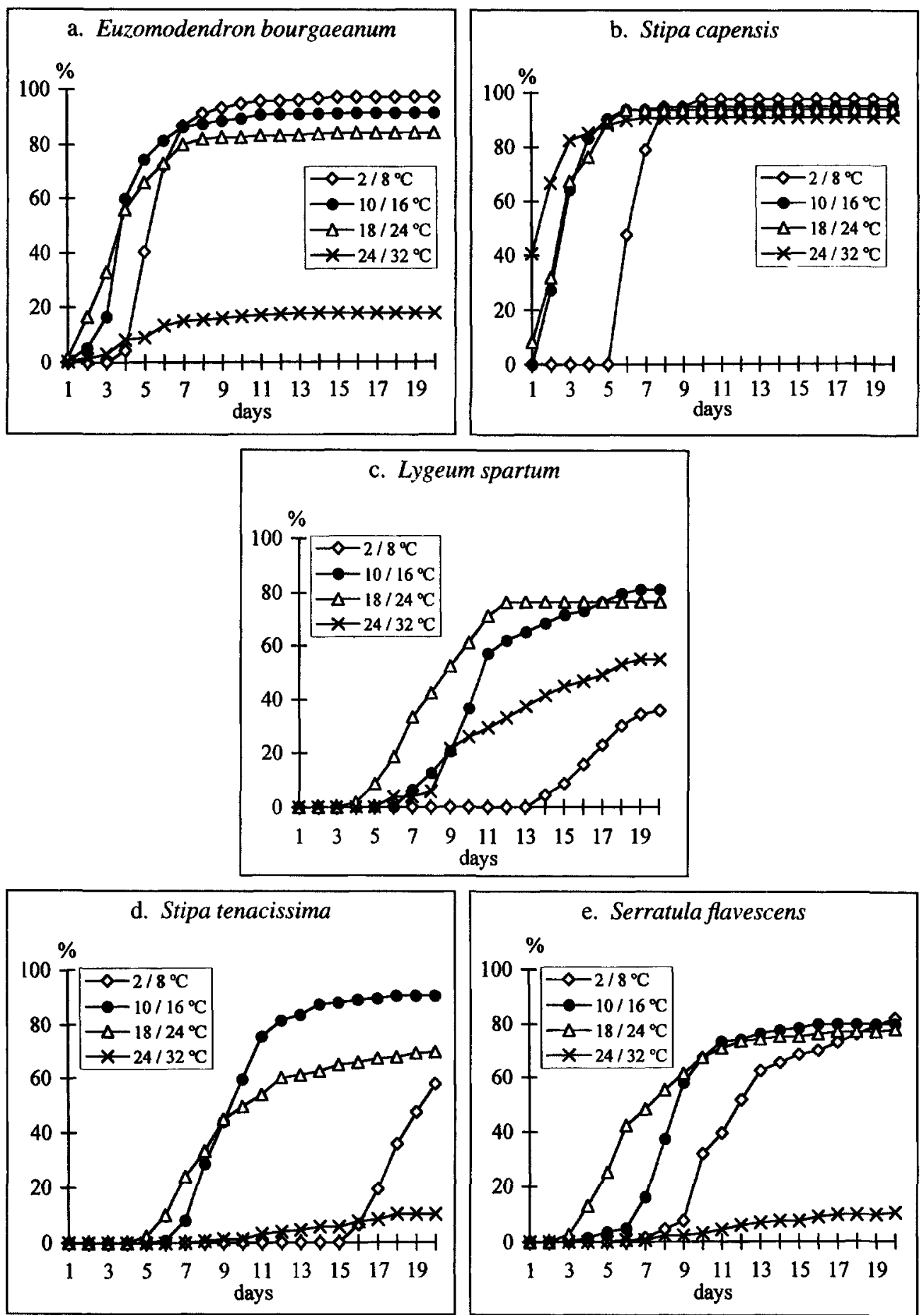

Fig. 7.-Percentages of germination of 6 month dry-stored diaspores at different diurnally fluctuating temperatures: a, Euzomodendron bourgaeanum; b. Stipa capensis; c, Lygeum spartum; d, Stipa tenacissima; e, Serratula flavescens. 
into mean group quantity fractions (GM), shows that perennial stayers of the chamaephytic life form are best adapted to this habitat. The most significant life strategy subdivision is that of perennial stayers with short-range dispersal and sexual reproduction followed by perennial stayers with longrange dispersal and sexual reproduction. Reproduction takes place mainly by sexually produced diaspores, which represent the most resistent stage of a plant's life history. It is remarkable that species spreading laterally are rare due to extreme water conditions, and clonal reproduction is nearly without significance for colonization and maintenance of this badland surfaces (table 4). However, this does not apply to the semi-desert habitat in general, as shown by HeNSEN (1999c).

As previously reported for several deserts or semi-deserts (e. g. GUTTERMAN, 1993), also most species of the Anabasio-Euzomodendretum bourgaeani mature and fructify shortly before or during the hot and rainless summer (see NAVARRo \& al., 1993). Therefore, their offspring success is influenced not only by the unpredictability of precipitation and by the high summer temperatures, but also by strong winds and seed-harvesting ants (see HENSEN, 1999b). The open vegetation structure of Anabasio-Euzomodendretum bourgaeani, the strong slope inclination of its locality, and the formation of a soil crust suggest that a high percentage of diaspores is most likely carried away from its current habitat by wind or flowing water.

A high percentage of the observed species within Anabasio-Euzomodendretum bourgaeani stores at least a part of their seeds in an aerial diaspore bank during the drought period (aestatiphory; table 3). This mechanism protects the species from heavy losses of diaspores, and assures that dispersal and germination coincide with an advantageous soil water supply. In autumn, seed release may be triggered by moisture (EVENARI \& al., 1982; GUTTERMAN, 1990). Therefore, for most aestatiphorous plants, the time of dispersal is close to that of seed germination. This dispersal peculiarity may help to retain a proportion of seeds sufficient to maintain the population within the habitat (GUTTERMAN, 1993).

The species dispersing their diaspores immediately after fruit maturity possess further mechanisms to survive the long unfavourable time between the short growing periods. Seeds of several species collected in the Tabernas Desert are protected by inhibited germination under extreme temperatures (e.g. Euzomodendron bourgaeanum, Serratula flavescens, Stipa parviflora, S. tenacissima, figs. 7a, d, e), whereas the existence of innate dormancy plays a minor role as expected (comp. e.g. MOTT, 1972; HARPER, 1977; FENNER, 1991; JURADO \& WeSTOBY, 1992; GutTerman, 1993; SchÜtZ \& Milberg, 1997).

The results of the present life strategy analysis reveal that there is a notable tendency towards short-range dispersal within Anabasio-Euzomodendretum bourgaeani. Biologically, the production of mucilage is one of the most important mechanisms to reduce dispersal in species such as Euzomodendron bourgaeanum, Moricandia foetida, Artemisia herba-alba, etc. (table 3, 4; fig. 5). Myxospermy is an effective mechanism of adhesion to the soil (GRUBERT, 1974; GutTerman, 1993; GutTERMAN \& SHEMTov, 1997a), and appears to decrease a secondary dispersal by wind or rain and seed predation by ants (GUTTERMAN, 1990, 1993; GUTTERMAN \& SHEM-Tov, 1997b). Although types and structure of mucilage differ considerably among the investigated diaspores, their adhesiveness under natural conditions is very strong. The significance of mucilaginous seeds under humid conditions is best described by the character species Euzomodendron bourgaeanum. To be effective, myxospermy requires conditions of variable atmospheric humidity. Thus, the myxophorous seeds of Euzomodendron bourgaeanum mature successively during spring when sporadic showers could still occur. The time of germination is regulated by the duration and degree of wetting, as well as by the presence of moderate soil temperatures. Germination usually does not occur until autumn in this 
group of plants (see SCHÜTZ \& MiLBERG, 1997 for Launaea arborescens). The combination of perennial life history, avoidance of secondary transport and predation, and the delay of germination until the rainy season results in a strong emphasis on permanent habitat colonization and maintenance.

The other significant life strategy subdivision of Anabasio-Euzomodendretum bourgaeani, perennial stayers with longrange dispersal and sexual reproduction, is characterized by telechory as prevailing dispersal behaviour. These species have not developed mechanisms for hindering or preventing dispersal. However, it is important to note that several of these species mature and disperse their diaspores during the rainy season when the time of germination is close to that of dispersal, and long-range dispersal is probably less likely to occur due to the moist climate conditions (see HENSEN, 1999a, for Salsola genistoides).

The results of the present life strategy analysis demonstrate that under alternating site conditions, the maintenance of habitat is of great importance for the regeneration success of the species. Considering the tendency towards short-range dispersal, Anabasio-Euzomodendretum bourgaeani is comparable to several already described xerothermous plant communities of Central Europe, such as e.g. Drabo-Hieracietum humilis (FREY \& al., 1995a), Stipetum capillatae, Adonido-Brachypodietum pinnati (HENSEN, 1997), or Carex humiliscommunity (BöTrNER \& al., 1997). In open landscapes, many sites to which a seed might be transported, will never be suitable for germination and establishment. Thus, the maintenance of habitat prevails over dispersal, and the new offspring is retained at the parental site which has already been proved to be favourable for the existence of the species.

Several species of Anabasio-Euzomodendretum bourgaeani are restricted to the Tabernas Desert. The threat of this semidesert landscape seems to be low, due to its sparse vegetation coverage which even grazing animals subsisting on very little can- not feed on. Nevertheless, it has to be kept in mind that due to the tendency towards shortrange dispersal, the habitat colonized by Anabasio-Euzomodendretum bourgaeani will never fall below the minimum necessary for maintaining the complete species variety. Thus, a further size reduction or a further habitat fragmentation will have to be prevented. Fortunately, a large step in the right direction has already been made by the establishment of the "Paraje Natural del Desierto de Tabernas".

\section{ACKNOWLEDGMENTS}

This research was supported by the DAAD programme "Acciones Integradas Hispano-Alemanas". I gratefully acknowledge the invaluable cooperation and helpfulness of Prof. Dr. J. Guerra, Dr. R. Ros, Dr. P. Sánchez and Dr. M. Cano (University of Murcia, Spain). Additionally, I would like to thank Prof. Dr. W. Frey for constructive comments on this manuscript, H. Lünser for drawing the figures 1,3 , and 4, S. Iorgova, Stanford University, for help with translation, and two anonymous reviewers for improvements in this article.

\section{REFERENCES}

Barkman, J.J., H. Doing \& S. Segal (1964). Kritische Bemerkungen und Vorschläge zur quantitativen Vegetationsanalyse. Acta Bot. Neerl. 13: 394-419.

BótTner, I., W. Frey \& I. Hensen (1997). Carex humilis-Gesellschaft im unteren Unstruttal (mitteldeutsches Trockengebiet) - Lebensstrategien in einer xerothermen Vegetationseinheit. Feddes Repert. 108: 425-452.

Braun-Blanquet, J.-J. (1964). Pflanzensoziologie, ed. 3. Berlin, Wien, New York.

Castroviejo, S., M. Lafnz, G. López-González, P. Montserrat, F. MuÑoz Garmendia, J. Paiva \& L. VILLAR (eds.) (1990). Flora iberica 2. Madrid.

Castroviejo, S., C. Aedo, S. Cirujano, M. Lainz, P. MontserRat, R. Morales, F. MuÑoz Garmendia, C. Navarro, J. Paiva \& C. Soriano (eds.) (1993a). Flora iberica 3. Madrid.

Castroviejo, S., C. Aedo, C. Gómez Campo, M. Laínz, P. MontserRat, R. Morales, F. MuÑoz GARMENDIA, G. Nieto Feliner, E. Rico, S. Talavera \& L. Villar (eds.) (1993b). Flora iberica 4. Madrid.

Castroviejo, S., C. Aedo, M. Laínz, R. Morales, F. Muñoz Garmendia, G. Nieto Feliner \& J. Paiva (eds.) (1997a). Flora iberica 5. Madrid. 
Castroviejo, S., C. Aedo, C. Benedi, M. Lafnz, F. MuÑoz Garmendia, G. Nieto Feliner \& J. Paiva (eds.) (1997b). Flora iberica 8. Madrid.

DIERSCHKE, H. (1994). Pflanzensoziologie. Stuttgart.

DURING, H.J. (1979). Life strategies of bryophytes: a preliminary review. Lindbergia 5: 2-18.

DURING, H.J. (1981). Bryophyte flora and vegetation of Lanzarote, Canary Islands. Lindbergia 7: 113-125.

DURING, H.J. (1992). Ecological classification of bryophytes and lichens. In: Bates, J.W. \& H.M. Farmer (eds.), Bryophytes and lichens in a changing environment: 1-31. New York.

Evenari, M., L. Shanan \& N. TADmor (1982). The Negev - the challenge of a desert, ed. 2. Cambridge.

FENNER, M. (1991). The effects of the parent environment on seed germinability. Seed Sci. Res. 1: 75-84.

FreITAG, H. (1971). Die natürliche Vegetation des südostspanischen Trockengebietes. Bot. Jahrb. Syst. 91: 147-308.

FreY, W. \& A. HAUSER (1996). Onopordetum acanthii (Eselsdistel-Gesellschaft) im mittleren und unteren Unstruttal - Lebensstrategien in einer wärmeliebenden Ruderalgesellschaft. Haussknechtia Beih. 6: 1-84.

FreY, W. \& I. HENSEN (1995a). Lebensstrategien bei Pflanzen: ein Klassifizierungsvorschlag. Bot. Jahrb. Syst. 117: 187-209.

FREY, W. \& I. HENSEN (1995b). Spergulo morisoniiCorynephoretum canescentis (FrühlingssparkSilbergrasflur) - Lebensstrategien von Binnendünenund Lockersandbesiedlern. Feddes Repert. 106: 533553.

FrEY, W. \& H. KúRSCHNER (199la). Lebensstrategien von terrestrischen Bryophyten in der Judäischen Wüste. Bot. Acta 104: 172-182.

FREY, W. \& H. KÙRSCHNER (1991b). Lebensstrategien epiphytischer Bryophyten im tropischen Tieflandsund Bergregenwald am Mt. Kinabalu (Sabah. NordBorneo). Nova Hedwigia 53: 307-330.

FreY, W. \& H. KurSCHNER (1995a). Bryosoziologische Untersuchungen in Jordanien. 3. Lebensstrategienanalyse der terrestrischen und epilithischen Moosgesellschaften. Fragm. Florist. Geobot. 40: 491-511.

FREY, W. \& H. KuRSCHNER (1995b). Soziologie und Lebensstrategien epiphytischer Bryophyten in Israel und Jordanien. Nova Hedwigia 61: 211-232.

Frey, W., I. Hensen \& H. KUrschner (1995a). DraboHieracietum humilis (Habichtskraut-Felsspaltengesellschaft) - Lebensstrategien von Felsspaltenbesiedlern. Bot. Jahrb. Syst. 117: 249-272.

FreY, W.. H. KüRSCHNER \& U.H. SEIFERT (1995b). Scientific results of the BRYOTROP expedition to Zaire and Rwanda. 7. Life strategies of epiphytic bryophytes from tropical lowland and montane forests, ericaceous woodlands and the Dendrosenecio subparamo of the eastern Congo basin and the adjacent mountains (Parc National de KahuziBiega/Zaire,Forêt de Nyungwe/Rwanda). Trop. Bryol. 11: 129-149.

FREY, W. \& R. LosCH (1998). Lehrbuch der Geobotanik. Stuttgart. Jena, Lübeck, Ulm.
González-Mancebo, J.M., A. Losada-Lima, C.D. HERNÁNDEZ \& H.J. DURING (1992). Bryophyte flora of volcanic caves in the Azores and the Canary Islands. Lindbergia 17: 37-46.

GroenKe, T. (1999). Dactylo hispanicae-Lygeetum sparti - Lebensstrategien in einer thermomediterranen Rasengesellschaft (Südostspanisches Trockengebiet, Almeria). Degree diss., Berlin.

Grubert, M. (1974). Studies on the distribution of myxospermy among seeds and fruits of Angiospermae and its ecological importance. Acta Biol. Venez. 8: 315-551.

GuTTERMAN, Y. (1990). Seed dispersal by rain (ombrohydrochory) in some of the flowering desert plants in the deserts of Israel and the Sinai Peninsula. Mitt. Inst. Allg. Bot. Hamburg 23: 841-852.

GutTERMAN, Y. (1993). Seed germination in desert plants. Berlin.

GutTerman, Y. \& S. SHEM-Tov (1997a). Mucilaginous seed coat structure of Carrichtera annua and Anastatica hierochuntica from the Negev Desert highlands of Israel, and its adhesion to the soil crust. J. Arid Env. 35: 695-705.

GuTterman, Y. \& S. SHEM-Tov (1997b). The efficiency of the strategy of mucilaginous seeds of some common annuals of the Negev adhering to the soil crust to delay collection by ants. Israel J. Plant Sci. 45: 317-327.

HalfmanN, J. (1991). Die Struktur der Vegetation auf periglazialen Basaltblockhalden des Hessischen Berglandes. Bryophytenvegetation und Waldgesellschaften: Morphologisch-anatomische Merkmale, Fortpflanzungs- und Ausbreitungsbiologie. Diss. Bot. 168: 1-212.

HARPER, J.L. (1977). Population biology of plants. London.

HENSEN, I. (1997). Life strategy systems of xerothermic grasslands - mechanisms of reproduction and colonization within Stipetum capillatae s.l. and Adonido-Brachypodietum pinnati. Feddes Repert. 108: 425-452.

Hensen, I. (1998). Life strategies in salt marsh communities of the East Frisian North Sea Coast (Northwestern Germany). Fragm. Florist. Geobot. 43: 237-256.

Hensen, I. (1999a). Reproductive patterns in five important semi-desert perennials of Southeastern Spain. Bot. Jahrb. Syst. 121 (in press).

HENSEN, I. (1999b). A comparative analysis of dispersal strategies in semi-desert plant communities of Southeastern Spain and xerothermic plant communities of Eastern Germany. Flora (in press).

HENSEN, I. (1999c). Life strategies in a widespread thermomediterranean grassland community mechanisms of dispersal and reproduction within Lapiedro martinezii-Stipetum tenacissimae (semiarid Southeastern Spain). Feddes Repert. 110 (in press).

Hensen, I. \& M. Kentrup (1998). Teucrio botryosMelicetum ciliatae (Traubengamander-Wimperperlgrasflur) - Lebensstrategien in einer xerothermen Fels-Pioniergesellschaft. Tuexenia 28: 217-236. 
Hensen, I. \& C. MUller (1997). Experimental and structural investigations of anemochorous dispersal. Plant Ecol. 133: 169-180.

HeNSEN, I. \& S. ZuTHER (1999). Die Anthyllis cytisoidesGesellschaft im südostspanischen Trockengebiet Lebensstrategien in einer mesomediterranen Ersatzgesellschaft. Tuexenia 19 (in press).

JENNY, M. (1995). Dispersal and micro-habitat conditions within a desert plant community (Wadi Araba, Jordan). Bot. Jahrb. Syst. 116: 483-504.

JURADO, E. \& M. WeSTOBY (1992). Germination biology of selected central Australian plants. Austr. J. Ecol. 17: $341-348$

KÚRSCHNER, H. (1994). Adaptationen und Lebensstrategien in basiphytischen Gesteinsmoosgesellschaften am Nordrand der Schwäbischen Alb (Süddeutschland). Phytocoenologia 24: 531-558.

MoTT, J.J. (1972). Germination studies on some annual species from an arid region of Western Australia. J. Ecol. 60: 293-304.

Navarro, T. (1995). Revisión del género Teucrium L. sección Polium (Mill.) Schreb. (Lamiaceae) en la Península Ibérica y Baleares. Acta Bot. Malac. 20: 173-265.

Navarro, T., J.M. Nieto Caldera, A.V. Pérez LatoRRE \& B. CABEzUdo (1993). Estudios fenomorfológicos en la vegetación del sur de España. III. Comportamiento estacional de una comunidad de badlands (Tabernas, Almería. España). Acta Bot. Malac. 18: 189-198.

Peinado, M., F. Alcaraz \& J.M. Martínez-ParRas (1992). Vegetation of Southeastern Spain. Berlin.

SCHRAMM, G. (1998). Astragalo-Velletum spinosae Lebensstrategien in einer Dornpolstergesellschaft aus den südostspanischen Betischen Kordilleren. Degree diss., Berlin.

SchUTZ, W. \& P. MLLBERG (1997). Seed germination in Launaea arborescens: a continuously flowering semidesert shrub. J. Arid Environm. 36: 113-122.

STEARNS, S.C. (1976). Life history tactics: a review of the ideas. Quart. Rev. Biol. 51: 3-47.

Tutin, T.G., V.H. HeYwoOd, N.A. Burges, D.M. MOORE, D.H. VALENTINE, S.M. Walters \& D.A. WEBB (eds.) (1968-1980), Flora Europaea 2-5. Cambridge.

Tutin, T.G., N.A. Burges, A.O. Chater, J.R. EDMONDSON, V.H. HEYwOOD, D.M. MOORE, D.H. VALENTINE, S.M. WALTERS \& D.A. WebB (1993). Flora Europaea 1, ed. 2. Cambridge.

ZIPPEL, E. (1998). Die epiphytische Moosvegetation der Kanarischen Inseln. Bryophyt. Biblioth. 52: 1-149.

ZOHARY, M. (1937). Die verbreitungsökologischen Verhältnisse der Pflanzen Palästinas, Beih. Bot. Centralbl. 56: 1-155.

Editado por Pablo Vargas Aceptado para publicación: 3-V-1999 